\title{
Gender, Migration, and Work
}

Filipina Health Care Professionals to the United States

\section{Yen Le Espiritu}

\section{(2) OpenEdition}

\section{Journals}

Electronic version

URL: https://journals.openedition.org/remi/2343

DOI: $10.4000 /$ remi.2343

ISSN: $1777-5418$

\section{Publisher}

Université de Poitiers

\section{Printed version}

Date of publication: 29 May 2005

Number of pages: $55-75$

ISBN: 2-911627-39-3

ISSN: 0765-0752

Electronic reference

Yen Le Espiritu, "Gender, Migration, and Work", Revue européenne des migrations internationales [Online], vol. $21-n^{\circ} 1$ | 2005, Online since 02 September 2008, connection on 15 April 2022. URL: http:// journals.openedition.org/remi/2343 ; DOI: https://doi.org/10.4000/remi.2343

This text was automatically generated on 15 April 2022.

(c) Université de Poitiers 


\title{
Gender, Migration, and Work
}

\author{
Filipina Health Care Professionals to the United States
}

\section{Yen Le Espiritu}

1 The ferocity of U.S. (neo)colonial exploitation, the mismanagement of the Philippines by the country's coamprador elite, and the violence of globalized capitalism have flung Filipinos "to the ends of the earth" as contract workers, sojourners, expatriates, refugees, exiles, and immigrants (San Juan Jr., 1998: 190) ${ }^{1}$. Although Filipinos can be found in more than 130 countries and territories by the early 1990s, with most earning a living as short-term contract workers, the vast majority of the Filipinos who migrated to the United States have resettled there as "permanent"immigrants (Tyner, 1999). According to the 2000 U.S. census, Filipinos totaled 1,8 million, comprising the second largest immigrant group as well as the second largest Asian American group in the United States ${ }^{2}$. Filipino migration to the United States differs in many respects from that to other labor-importing states. The history of U.S. colonialism in the Philippines, combined with a relatively liberal U.S. immigration policy and the proximity to alternative "cheapened" labor supplies, particularly from Central America and the Caribbean, means that a larger proportion of Filipino immigrants in the United States than elsewhere find employment in higher status and higher skilled occupations (Tyner, 1999).

2 Since 1960, women have dominated Philippine labor flows to the United States. In 2000, of the roughly 43000 Filipinos who immigrated to the United States that year, 61 percent were women (U.S. Immigration and Naturalization Service, 2000). Unlike their counterparts in Europe, the Middle East, and East Asia, the majority of whom are contract domestic workers, Filipina immigrants in the United States are decidedly more concentrated within professional sectors, a phenomenon that can be largely accounted for by the migration of Filipina health care professionals, especially nurses (Tyner, 1999). Since the 1970s, the Philippines has been the largest supplier of health care professionals to the United States, sending nearly 25000 nurses to this country between 1966 and 1985 and another 10000 between 1989 and 1991. In 1989, Filipino nurses comprised close to 75 percent of the U.S.'s total foreign nurses; in 2003, this figure had climbed to 85 percent (Ong and Azores, 1994; Advincula, 2004). In fact, many 
women (and increasingly men) in the Philippines studied nursing in the hope of securing employment abroad, and many of the nursing programs in the Philippines accordingly oriented themselves toward supplying the overseas markets (Ong and Azores, 1994) ${ }^{3}$.

There is a widespread assumption - in the scholarly literature as well as in the popular imagination - that immigrants, especially those from developing countries, come to the United States primarily for economic reasons such as obtaining a higher income and standard of living. These economic explanations are well documented in the "pushpull" approaches to the study of migration. The neo-classical economic theory casts the individual migrant as a calculating economic agent, weighing the benefits and costs of migrating from low-wage to high-wage economies (Thomas, 1973; Borjas, 1990); and the updated "new economics of labor migration" (Stark, 1991) approach claims that migration decisions are made not just by individuals but by the whole family to maximize the household income and survival chances (Massey et al, 1993; Taylor, 1999). But migrants do not act in a vacuum devoid of historical and political context. Linking U.S. imperialism and migration to the United States, I argue that the overrepresentation of health professionals among contemporary Filipino immigrants is the result of intertwined influences of U.S. (neo)colonialism in the Philippines, deliberate recruitment from U.S. health institutions, transnationalism, and gender ideologies and practices in both the Philippines and the United States. As a much sought-after group among U.S. immigrants, Filipina health care nurses can enter the United States as principal immigrants. A female-first migration, especially when the women are married, has enormous ramifications for both gender roles and family relations. Therefore, in the second half of the article, I examine how migration processes, labor recruitment practices, and employment conditions have reconfigured gender and family relations for Filipina health-care professionals.

\section{A critical transnational perspective to migration studies}

4 Transnational migration studies form a highly fragmented field; there continues to be much disagreement about the scope of the field and the outcome of the transnational processes under observation (Portes, Guarzino, and Landolt, 1999; Glick Schiller, 1997). From an epistemological stance, I find transnationalism to be a valuable conceptual tool, one that disrupts the narrow emphasis on "modes of incorporation" characteristic of much of the field of U.S. immigration studies and highlights instead the range and depth of migrants' lived experience in multinational social fields (Levitt, 2001; Glick Schiller and Fouron, 2001; Perez, 2004). In this paper, I employ a critical transnational perspective to call attention to yet another way of thinking beyond the limits of the nation-state: one that stresses the global relations that set the context for immigration and immigrant life. That is, today's global world is not just some glorious hybrid, complex, mixity; it is systematically divided and historically produced (Guarnizo and Smith, 1999; Massey, 1999).

5 In the United States, public discussions about immigration fundamentally centers on people who cross borders. However, the media, elected officials, and the general public often represent border crossers to be desperate individuals migrating in search of the "land of opportunity." From the perspective of immigration restrictionists, immigrants 
unfairly "invade" the United States, drain its scarce resources, and threaten its cultural unity (Perea, 1997). Besides fueling nativist hysteria, this anti-immigrant rhetoric makes invisible other important border crossers: U.S. colonizers, military, and corporations that invade and forcefully deplete the economic and cultural resources of less-powerful countries (Lipsitz, 1998: 54). Given these multiple forms of border crossings, a critical approach to immigration studies must begin with the unequal links between First and Third World nations forged by colonization, decolonization, and the globalization of late capitalism. A critical transnational perspective that stresses the global structures of inequality is critical for understanding Asian immigration and Asian American lives in the United States. Linking global economic development with global histories of colonialism, Edna Bonacich and Lucie Cheng (1984) argue that the pre-World War II immigration of Asians to the United States has to be understood within the context of the development of capitalism in Europe and the United States and the emergence of imperialism, especially in relation to Asia. From World War II onward, as the world economy has become much more globally integrated, Asia has been a site of U.S. expansion. As a result, contemporary immigrants from the Philippines, South Vietnam, South Korea, Cambodia, and Laos come from countries that have been deeply disrupted by U.S. colonialism, war, and neocolonial capitalism (Lowe, 1996; Campomanes, 1997).

In the case of the Philippines, the prior flow of population, armies, goods, capital, and culture - moving primarily from the United States to the Philippines - profoundly dislocated many Filipinos from their home and subsequently spurred their migration to the United States and elsewhere. In 1898, in the aftermath of the Spanish-American War, the United States brutally took possession of the Philippines over native opposition and uprising, thereby extending its "Manifest Destiny" to Pacific Asia. U.S. colonialism (1898-1946) stunted the Philippine national economy, imposed English as the lingua franca, installed a U.S.-style educational system, and Americanized many Filipino values and aspirations (Espiritu, 2003: Ch. 2). Even long after the Philippines regained its independence in 1946, the United States continued to exert significant influence on the archipelago - through trade, foreign assistance, and military bases. Infected with U.S. colonial culture and images of U.S. abundance, and saddled by the grave economic and political conditions in the Philippines, many Filipinos migrated to the United States to claim for themselves the promises of the "land of opportunity" (Espiritu, 2003: Ch. 2).

\section{U.S. colonialism, labor recruitment and the production of filipina nurse migrants}

7 Although many scholars have conceptualized the contemporary Filipina nurse migration to the United States as a post-1965 phenomenon ${ }^{4}$, Catherine Choy (2003) argues that we need to trace the origins of this international migrant labor force back to early twentieth-century U.S. colonialism in the Philippines. According to her, the introduction of nursing in the Philippines was part of a larger U.S. colonial attempt to "civilize" and "sanitize" the medically defective Filipino bodies under the guise of benevolent rule. In a nuanced analysis of the role of colonial medicine in the formation of colonial hegemony, Warwick Anderson (1995) delineates the ways by which the language of American medical science in the Philippines fabricated and rationalized 
images of the bodies of the American colonizers and the Filipinos - and in so doing, biologizing the social and historical context of U.S. imperialism. The scientific papers produced by the colonial laboratory during the early 1900s racialized Filipino bodies as dangerous carriers of foreign antibodies and germs that threatened white bodies; and American bodies as vulnerable but resilient, capable of guarding against the invisible foreign parasites lodged in native bodies ${ }^{6}$. The fears of the "innately unhygienic" Filipinos led to and justified house-to-house sanitary inspections and the quarantining of the "sick" from the communities. As such, the American medial discourse, as a privileged site for producing the "truth" about the "tropics," served to consolidate racial hierarchies, naturalizing the power and legitimacy of American foreign bodies to appropriate, command, and contain the Philippines and its people.

Like previous American medical interventions, the introduction of nursing in the Philippines reinforced many of the racialist functions and beliefs of Western medicine - all in the name of a humane imperialism. The opening of the first government school of nursing school in the Philippines in 1907 was part of the larger U.S. colonial project of transforming Filipino bodies into a strong and healthy people capable of self-rule. In other words, the racialist construction of the Philippines as always-already diseased justified the need for more American medical intervention in the form of nursing. Viewing the teaching of nursing to Filipinos as a "moral obligation", American nursing educators often derided their young Filipina charges for their perceived temporal backwardness, "primitive" health practices, and lack of "rudimentary knowledge" about sanitation (Choy, 2003: 23-25). For their part, despite their initial rebuff of the idea of women nursing, Filipinas who attended American-founded nursing schools gradually learned American nursing work culture, gained English fluency, and came to associate the United States with glamour, opportunity and upward mobility. Professional nursing provided them with newfound opportunities to interact with colonial government officials, to attend government functions, to enter a prestigious profession, to serve their country - and most of all, to travel (Choy, 2003).

9 In the early twentieth century, as part of their effort to acculturate elite Filipinos and to augment their devotion to the United States, the U.S. colonial government sent several hundred individuals, including those in nursing, to study in U.S. colleges and universities. Highly selected, these pensionados often were the children of prominent Filipino families whose loyalty the colonial regime hoped to win (Lawcock, 1975; Posadas and Guyotte, 1990). As anticipated, these early exchange programs, which brought Filipinos to the United States for "advanced training", reconstructed a global, cultural, and intellectual hierarchy in which U.S. institutions

- educational, political, medical - were superior to those of the Philippines. As exchange visitors, Filipina nurses became Philippine cultural ambassadors in the United States, and U.S. nursing ambassadors upon their return to the Philippines. The possibilities of going to America as exchange students and nurses dramatically increased nursing's popularity. Eventually, studying and working abroad in the United States became a de facto prerequisite for occupational mobility in the nursing profession in the Philippines.

10 During the post-World War II period, the establishment of the Exchange Visitor Program (EVP) in 1948, which allowed visitors to stay in the United States for two years for training, made the dream of going abroad to the United States a possibility not only for elite women, but for the majority of nurses in the Philippines. The prestige 
associated with study and work abroad propelled Filipino nurses to transform the EVP into an avenue for the first wave of mass migration of nurses to the United States, even despite troubling reports of exploitation by U.S. hospitals, which largely regarded the exchange nurses as a "cheapened" workforce. By the late 1960s, 80 percent of exchange visitors in the United States were from the Philippines, with nurses comprising the majority of the participants (Asperilla, 1976). The long-established presence of an Americanized professional nursing training system in the Philippines coupled with the existence of a transnational community of Filipino nurses created by the EVP, laid the professional, social, and cultural groundwork for a "feminized, highly-educated and exportable labor force" (Choy, 2003: 13). Goaded by grave economic and political conditions in the Philippines, this available labor force took full advantage of the relaxation of U.S. immigration rules and preference for health care professionals in 1965 to migrate en masse to the United States. Like other immigrants, Filipina migrant nurses have had to accept inequitable pay and work arrangements in exchange for the comparatively higher salaries and immigration opportunities available in the United States (Ong and Azores, 1994).

11 The overrepresentation of health professionals among contemporary Filipino immigrants is also the result of deliberate and aggressive recruitment from U.S. hospitals, nursing homes, and health organizations, seeking a "cheapened" workforce ostensibly in response to domestic shortages in trained nurses (Ong and Azores, 1994; Chang, 2000). Since the passage of the 1965 Immigration Act, U.S. health organizations, in collaboration with Philippine travel agencies, actively recruited Filipino nurses, especially former exchange nurses, to migrate to the United States for permanent employment in their institutions. Many hospitals and nursing homes recruited workers via the H-1 nursing visa program, which enabled them to sponsor nurses from abroad on temporary work visas to fill permanent positions ${ }^{7}$. Recruitment advertisements, conspicuously placed in the major local newspapers and in the Philippine Journal of Nursing, promised potential migrants interest-free loans for travel expenses as well as such bonuses as continuing education, tuition assistance at U.S. universities, a higher salary, health plans, pension plans, paid vacation, and sick leave (Ong and Azores, 1994; Choy, 2003: 99-101, 107). However, in their aggressive hunt for nurses, nurse recruiters have often misinformed recruited nurses about U.S. licensing requirements, educational credentials, work conditions, and pay and benefits. Some recruiters demanded a "fee" averaging $\$ 7000$ to $\$ 9000$ from the recruitees, ostensibly to pay for the recruiter's fee and to arrange the nurse's visa. Since few women could afford this fee, most agreed to have it deducted from their meager monthly wages, a condition that left many H-1 immigrants in "debt peonage for at least two years" (Chang, 2000; also Choy, 2003: 173; Ong and Azores, 1994).

\section{Gender and migration: the formation of a gendered labor force}

12 The field of gender and immigration research has moved from the "immigrant women only" approach that emphasizes sex differences in migration systems to one that examines how gender as a social system contextualizes migration processes for both women and men (Hondagneu-Sotelo, 1999; Tyner, 1999). In particular, this scholarship has interrogated the ways in which constructions of masculinities and femininities 
organize migration and migration outcomes (Hondagneu-Sotelo, 1994). Although the concept of gender is invaluable for the understanding of migration experiences, women of color have argued that the gender process cannot be understood independently of class and race and other structures of oppression (Espiritu, 1997; Glenn, 2002). Accordingly, contemporary approaches to migration have increasingly questioned the premise of a universal, shared experience of womanhood and have developed theories and designed research that capture the multiple and mutually constitutive relations of race, class, nationality, and legal status (Pessar, 1999).

Gender beliefs, often working in tandem with and through racial beliefs, affected the content and scope of U.S. colonialist policies and practices in the Philippines. As feminist theorists have reminded us, the construction of "otherness" is achieved not only through racial but also through sexual and gendered modes of differentiation (Mohanty, 1991; Stoler, 1991; Yegenoglu, 1998). Attentive to the mutually constitutive aspects of race and gender, historian Kristin Hoganson (1998) has shown how the racialization of Filipinos as biologically unfit for independence drew on ideas about gender. Through a careful reading of a range of official and cultural discourses of the time, she convincingly demonstrates that the prominent stereotypes of the Filipinos as uncivilized, savages, rapists, or children - all presented the Filipinos as lacking the manly character seen as necessary for self-government. She adds to this list the stereotype of the feminized Filipino: the depiction of the Philippines as woman, Filipino men as effeminate, and Filipino women as highly feminine and sexualized (Hoganson, 1998: 137). The hyperfeminization of Filipino men and women misrepresented and distorted gender relations in the Philippines, pitting the two sexes against each other. They also bolstered the racialized conviction that Filipino men lacked the manly character for self-government and justified the need for U.S. interventions to rectify the Philippine "unnatural" gender order (Espiritu, 2003). The extensive U.S. military presence in the Philippines (1898-1992) has also produced stereotypes of Filipinas as desirable but dangerous "prostitutes" and/or submissive "mail-order" brides (Halualani, 1995; Egan, 1996). Many Filipino nationalists have charged that the "prostitution problem" in the Philippines stemmed from U.S. and Philippine government policies that promoted a sex industry - brothels, bars, and massage parlors - for U.S. servicemen stationed or on leave in the Philippines. During the Vietnam War, the Philippines was known as the "rest and recreation" center of Asia, hosting approximately ten thousand U.S. servicemen daily (Coronel and Rosca, 1993; Warren, 1993). In this context, all Filipinas were racialized as sexual commodities, usable and expendable. These established images often "travel" with Filipinas overseas and prescribe their racialization there. For example, Christine Chin (1998: 144-46) reports that many middle-class Malaysian employers regard their Filipina domestic workers as sexually promiscuous and thus in need of intense methods of surveillance and control.

14 U.S. colonial nursing in the Philippines highlights the complex intersections of gender ideologies with those of race and class in shaping U.S. colonial agendas and practices. U.S. colonial training of Filipino nurses, recruited primarily from "respectable" families, involved the imposition of America's gendered (and also racialized and classed) assumptions about labor, which, as feminist scholar Louise Newman (1999: 34) points out, posited that "the more civilized the race, the more the men and women of that race had to differ from one another." Since American women colonialists linked 
differentiated gender roles with racial progress, they viewed the construction of a separate sphere of Filipino women nurses to be foundational to the uplift of the Filipino race. Thus the gendered notions of nursing as women's work

- widely accepted in early twentieth-century white middle-class America - was an idea that American nursing educators "actively had to reproduce" in the Philippines (Choy, 2003: 26). U.S. colonial government deliberately separated and excluded Filipino men from the labor of nursing; it also attempted to legislate the creation of a female nursing labor force through a 1909 act that appropriated funds for women-only nursing classes (Choy, 2003: 44). The construction of this gendered labor force - and gendered form of mobility - would lay the foundation for the significant women-dominated migrations of Filipino nurses beginning in the second half of the twentieth century.

The women-dominated migrations of Filipino nurses also reflect women's segmentation into nursing professions in the United States (Tyner, 1999). The endemic and recurring shortage of nurses in the United States constitutes the primary underlying factor for the recruitment of Filipino nurses to the United States. Although fueled by the rapid growth in the demand for health care and the changing character of U.S. medical care, the shortage of nurses is also the result of sex-based discrimination in the profession (Ong and Azores, 1994; Tyner, 1999). Since nursing was consistently women's work in the United States, wage levels in the field have been kept comparatively low. Even in a competitive market, where demand for nurses has consistently outstripped the supply of labor, wages for nurses have not risen to the levels needed to entice U.S.-born women to enter the field (Ong and Azores, 1994: 166). In response to this glaring wage disparity, nurses in the United States have unionized and filed comparable-worth suits to demand higher pay (Blum, 1991: 104-08; Hunter, 1986: Ch. 7). The lack of decent wages - coupled with poor working conditions and a lack of professional prestige - have induced many American nurses to leave the profession and others to shun these jobs (Ong and Azores, 1994; Tyner, 1999).

The U.S. chronic labor shortage of nurses, most acute in inner-city and rural facilities, has led to the active recruitment and continued preferential treatment of foreigntrained nurses in U.S. immigration laws. In response, since the 1970s, the Philippine government has actively promoted the export of its nurses in exchange for their remittance dollars, which are critically needed to alleviate the nation's mounting external debt and trade deficits 8 . Once denigrated for abandoning the health needs of their own people for the mighty dollar, Filipino nurses working abroad became the Philippines' new national heroes whose earnings would help to revitalize the nation's economy (Choy, 2003: 116). In a 1973 address to Filipino migrant nurses, Philippine Secretary of Health Clemente S. Gatmaitan proclaimed: “...we are proud of you. Another benefit that accrues from your work is the precious dollar you earn and send back to your folks at home. In this manner, you help indirectly in the improvement of our economic conditions" (cited in Choy, 2003: 117). Gatmaitan's declaration does not apply to nurses only, but reflects the Philippine nation-state's economic strategy since 1974: to "export" its workers worldwide in exchange for their remittances (Rafael, 2000: 205-206).

Philippine government officials and recruitment agencies exploit gendered depictions of Filipinas to market the Filipino nurses. As expected, these officials and agencies extol the nurses' English-speaking skills and American professional training, both a legacy of U.S. colonialism. However, in their aggressive promotion of the migration of nurses, 
they also praise Filipino nurses for their purported "tenderness" and natural knack for care giving, thereby relying and perpetuating stereotypical depictions of the "Oriental women" as inherently feminine and servile. In a 2001 speech commemorating the $103^{\text {rd }}$ founding anniversary of the Philippine Department of Foreign Affairs, Philippine Vice President and Foreign Affairs Secretary Teofisto T. Guingona, Jr. (2001) praised the Filipino migrant nurses' predisposition for the gendered work of nursing: "In Canada, in America, in Europe, and in other places Filipina nurses are in demand. Why? Because they do their job with a smile, with charm, with grace, with the real purpose of helping to ease the patients' pain, without looking at the clock, without minding the overtime, really trying to cure the patient and comforting him in his time of crisis. And that is why Filipino nurses are in demand." In addition to gendering the patient as male and the nurse as female, Guingona depicted the Filipina nurses as cheerful about and even welcoming of their harsh working conditions such as long hours and hard physical labor. In the same way, Annabelle Reyes Borromeo, founding president and CEO of STIUniversal Worker Inc., an international consulting firm based in the Philippines that specializes in training, educating, and preparing qualified nurses for careers abroad, imbued Filipina nurses with feminine virtues: "Our nurses need not necessarily be taught to care - they're natural at this - from the way we talk and touch, it's like second nature to us already and it's what they like about Filipino nurses" (The Manila Times, 2004).

\section{Female-first migration and changing gender relations}

18 Through the process of migration and settlement, patriarchal relations undergo continual negotiation as women and men rebuild their lives in the new country. An important task in the study of migration has been to examine this reconfiguration of gender relations. Central to the reconfiguration of gender hierarchies is the change in immigrant women's and men's relative positions of power and status in the country of settlement. Theoretically, migration may improve women's empowerment and social position if it leads to increased participation in wage employment, more control over earnings, and greater participation in family decision-making (Pessar, 1984). Alternatively, migration may leave gender asymmetries largely unchanged even though certain dimensions of gender inequalities are modified (Espiritu, 1997).

As a result of the recurring shortage of nurses in the United States, Filipina health care workers are a much sought-after group among U.S. immigrants, and thus can enter the United States as principal immigrants. This means that unmarried women can immigrate on their own accord and that married women can enter as the primary immigrants, with their husbands and children following as dependents. Drawing from in-depth interviews of Filipino Americans in San Diego', California, the rest of this paper explores the impact of the female-first migration of health-care professionals on gender and family relations. San Diego has long been a favorite site of settlement for Filipinos and is today the third largest U.S. destination of contemporary Filipino immigrants. In 2000, there were approximately 120000 Filipinos in San Diego County. Although these immigrants comprised only 4 percent of the country's general population, they constituted more than 50 percent of the Asian American population (Espiritu, 2003: 17). A 1992 survey of approximately 800 Filipino high school students in 
San Diego found that close to a quarter of the respondents' mothers worked in the field of health care, about half of whom were registered nurses (Espiritu and Wolf, 2001).

\section{"We were young and we wanted to see the world": Migration of single women}

Rose Ocampo grew up in Cavite among four sisters and three brothers as the fourth of eight children. She decided to become a nurse because "it was a trend": "All my friends were going into nursing so I went ahead and went into nursing too." Rose came to the United States in 1961 under the auspices of the U.S. Exchange Visitor Program (EVP). She explained that she and a friend wanted to visit the United States "to see the country." "It wasn't for the money", she said quickly. "The stipend was only a hundred dollars a month and they worked you forty eight hours a week." What the two young women wanted was "a new environment, for adventure. We were young and we wanted to see the world." Rose was sent to a small town in Minnesota, where she befriended other EVP Filipino nurses who helped her to integrate into her new community. When her exchange visa expired at the end of two years, Rose wanted to extend her stay because "my friends and I still wanted to go around the world." Instead of returning to the Philippines, she exited the United States by going to Canada where she worked for a year. However, just before she left for Canada, she befriended a Filipino American man who followed her to Canada. The two married a year later, which allowed Rose to officially immigrate to the United States.

Rose's experience illustrates the power of gender in shaping migration. First, it shows that gender-based transnational social networks circumscribe migration opportunities. Women nurses migrated to and settled in the United States with the help of other women. Through letters, phone calls, and return visits, Filipino nurses who had gone abroad created new expectations, goals, and desires among young Filipino women still in the Philippines. According to Luz Latus, her nursing friends' and colleagues' decisions to apply for U.S. visas influenced her own decision to emigrate:

After I graduated, I decided to come here. I thought, "Well, it seems like everybody wants to go there." So I thought I'd try. Why not, you know ? There is always a farewell party for so-and-so. She's leaving forthe U.S., to do this and that. Well, somehow, a whole bunch of us, we decided, let's go ahead and apply. You know how when you were young, I mean... you know, you're really, just want to experience this. What is this thing they're talking about? America.

In the process of relocating and settling in the United States, Filipino health-care migrants also created new transnational networks of support, helping each other to adjust to their new occupational, social, economic, and cultural settings (Choy, 2003).

Second, Rose's experiences reveal that men and women often give different reasons for migrating. When asked about their motivations for migrating to the United States, the Filipino men in my study tended to give the following reasons: to better represent themselves as able economic providers and desirable sexual partners. In contrast, while Filipina nurses also mentioned economic motives, many more cited desire to be liberated from gendered constraints: to see the world and experience untried ways of living (see also Parreñas, 2001: 62-69). The Exchange Visitor Program, and the new occupational preference categories of the 1965 Immigration Act, created opportunities for Filipina women health professionals to enter the United States on their own accord. Indeed, the majority of the nurses that I interviewed came to the United States initially 
as single women, a fact corroborated by other studies of Filipina nurses (Choy, 2003). In the interviews, many of these nurses represented their decision to come to the United States as an effort to push gender roles, especially to unshackle themselves from family discipline that hindered their individual development. For example, Cecilia Bonus indicated that she applied to study in the United States because "my family was just so protective. I just kind of wanted to get away and be independent." Being away from home enabled many young women to free themselves temporarily from strict parental control on their activities and movements. In the United States, many traveled freely, socialized widely, lived in their own apartments, and stayed out late at night.

Perhaps most important, Filipina health-care professionals reveled in their newfound freedom to befriend and date men. Carmen Reynila described how she and her fellow exchange nurses enjoyed the company of the Filipino sailors ${ }^{10}$ in town:

There used to be a lot of Filipino gatherings around. So you got to meet each other, and then the sailors, you know, they would come to our apartments, and then, you know, we would go out with them, but then always in a group [laughter]. Because I would say there is safety in numbers [laughter].

Many Filipino women seize their newfound freedom to make more independent choices about marriage. Some elected to marry in the United States, partly to mute any possible objections from their parents. In an example, Rosie Roxas, who met her Filipino Navy husband while in San Diego, explained why she did not return to the Philippines to marry, "My parents would not have approved of him. Their background... it would have been very difficult... They wanted me to marry a professional... He would not have passed." In her study of Filipino nurses, Choy (2003) reports that Philippine government health officials and nursing leaders used a rhetoric of spirituality and morality to create the new lifestyles of Filipino exchange nurses abroad. These critics charged that some Filipino exchange nurses had become morally corrupt and associated the nurses' new lifestyles in the United States with licentiousness. Choy accurately interprets these charges as efforts to persuade Filipino nurses to return to work in the Philippines. However, in light of the women's newfound independence, I believe these charges must also be viewed as retaliating moves to reassert patriarchal control over the bodies of these women.

\section{Negotiating changing gender roles: the migration of married women}

When the women are married, a female-first migration stream can have enormous ramifications for both family relations and domestic roles. In a reversal of historical patterns of migration, many married women health professionals enter the United States as primary immigrants, with their husbands and children following as dependents. Take Cecile Garcia's story, for example. Cecile had always dreamed of "America" and going abroad figured prominently in her decision to select a nursing career. In 1973, married with two young children, she left for the United States under the auspices of the Exchange Visitor Program. Although both she and her mechanic husband shared a desire to move the family to the United States, it was her profession that allowed them to do so. As an exchange nurse, she came alone; her husband stayed behind to care for their two young daughters. Eighteen months later, when she had successfully adjusted her status from exchange visitor to permanent resident, she petitioned for her family to join her. But the temporary separation from the children had its costs: 
My daughter who was two when I left didn't even know me when I went back to get them. She would not come to me. I stayed there for three weeks when I picked them up... still she would not come to me. I was very hurt by that. I was like a stranger... and that really struck me. I don't want to not be known by my children. men who immigrate as their wives' dependents experience downward occupational mobility in the United States, while their wives maintain their professional status. Pyong Gap Min (1998: 52) reports that among Korean immigrant families in New York, while Korean nurses hold stable jobs, many of their educated husbands are unemployed or underemployed. Gender role reversals - wives' increased economic role and husbands' reduced economic role - challenge men's sense of well-being and place undue stress on the family. For example, Elizabeth Mayor, a Filipina medical technologist, entered the United States in 1965 through the Exchange Visitor Program, leaving behind her husband and two sons. One year later, Elizabeth changed her status to permanent resident and petitioned for her family. Elizabeth's husband, who had a degree in criminology, could not find work comparable to his education and training in the United States. Elizabeth described their differential access to suitable employment:

For me, since I had the training in Illinois, and had my license as a med tech, I was able to work in the medical profession in the laboratory. I had no problems finding a job. But for him, it was difficult. He had to work odd jobs, anything that was available there. That was a minus for him... My husband was more dependent on me because I had a stable job.

Her husband was "bitter" about this role reversal: "He had a big problem. His selfesteem was really low. When he first came, he worked as a janitor, then as a dishwasher. He was working all the time but in blue-collar jobs. It took a lot out of his self-esteem, as far as that goes." Because of this loss of status, Elizabeth's husband repeatedly expressed his desire to return to the Philippines - for the entire duration of their thirteen-year stay in Illinois. In 1989, Elizabeth's sister urged them to leave Chicago and join the family business in San Diego. Although Elizabeth had a "good job" in Chicago, she decided to accept her sister's invitation, in part because it included a job offer for her husband. At the time of our interview in 1994, Elizabeth reported that her husband's self-esteem has been restored: "My husband is happy now. That was the first steady job he'd held since he came to the United States." In contrast, Elizabeth had difficulty finding a stable job and instead worked part-time for a local company. But Elizabeth expressed that she was content with her new life: "So it is just the opposite here. He has a steady job and now I work part time. Which I like too... As an Oriental, my upbringing is... usually the husband is the bread earner back home. So that worked perfect for me. It's a lot better for him here than back East. So I am happy." 

of opportunities that many immigrant men and women encounter in contemporary United States (Hondagneu-Sotelo, 1994; Espiritu, 1997; Menjivar, 1999). The dynamics of the U.S. economy, in this case the shortage of medical personnel, places many women in a relatively favorable position with respect to access to paid work, whereas their male peers do not fare as well. At the same time, Elizabeth's experience challenges the relative resource models that predict that as women's earnings rise relative to their husbands', their authority and status in the family will correspondingly rise. Elizabeth's story suggests that the labor market advantage does not automatically or uniformly lead to more egalitarian relations in the family. Instead, perceived cultural ideals about gender and spousal relations that were held in the Philippines, some of which was imported through U.S. colonialism such as the belief that the men should be the primary economic provider and head of the household, continue to influence the outcomes of the changing balance of resources in the new country.

\section{Working at family life}

of primary themes in gender and immigration research concerns the impact of immigrant women's employment on gender equality in the family. Like other case studies on gender relations among salaried professionals, my research on women health professionals indicates that women's employment has led to greater male involvement in household labor (Chen, 1992; Min, 1998; Pesquera, 1993). However, this more equitable household division of labor is not attributable to women's earning power, but rather to the women's demanding job schedules and to the couple's recognition that at least two incomes are needed to "make it" in this country. Like other immigrants, the health care professionals' success requires the work of the whole family, with husbands and children at times having to assume tasks not usually expected of them.

A survey of Filipino nurses in Los Angeles County reveals that these women, to increase their incomes, tend to work double shifts or the higher-paying evening shifts and night shifts (Ong and Azores, 1994: 183-184) ${ }^{11}$. Given the long hours and the graveyard shifts that typify a nurse's work schedule, many husbands have had to assume more childcare and other household responsibilities in their wives' absences. Some nurses have elected to work the night shift, not only because of the higher pay, but also because they can leave the children with their husbands instead of with paid child care providers. According to Cecilia Bonus, "I work mostly at night. So my husband takes care of the kids... He's pretty good at helping when I have to work... He's pretty understanding as far as that goes." Maricela Rebaya's mother took pride in the fact that she never left her children with baby-sitters:

We never had baby sisters. Oh, my mom is the toughest person in the world. She just managed. When she was in nursing, she would work at night. And my dad would take care of us when she was at work. So, like, in the morning, when she gets home, she makes breakfast for the kids, and then my dad drives us to school, and then she would go to sleep.

In her research on shift work and dual-earner spouses with children, Harriet Pressner (1998) finds that the husbands of night-shift workers do a significant part of child care; in most cases, it was the husbands who supervised the often-rushed routines of getting their children up and off to school or to child care.

Revue européenne des migrations internationales, vol. 21 - n¹ | 2005 

children, they sometimes rely on the eldest child to shoulder the responsibility. When Maria Galang turned fifteen, both of her parents worked the night shift: her mother as a nurse at the local hospital and her father as a janitor at the local mall. Maria was forced to take care of her younger sister during her parents' absence:

Because mom and dad worked so much, I had to assume the role of mother hen. And it was a strain especially at that point when I hit high school. They figure that I was old enough now. I remember frequent nights when my sister would cry and she wanted mom. What could I do? While mom and dad provided that financial support, we needed that emotional support as well which was often lacking.

This arrangement can take a toll on family relations: A child who has grown up without the mother's presence may no longer respond to her authority (Hondagneu-Sotelo and Avila, 1997: 562). As an example, for five years, Rose Dumlao "mothered" her younger brother while her Navy father was away at sea and her nurse mother was working long hours at the hospital. As a result, Rose's brother channeled his affection and respect to Rose, his "other mother," instead of to his mother:

I think the reason why my brother doesn't really respect my mom the way he should is because he never really saw my mom as the caretaker because she was never around. So even now, whenever my parents want my brother to do something, like if they have to talk to him, I have to be either in the room or I have to be the one that's talking to him because he's not going to listen to them. Because I spent more time with him.

Even when there are no younger siblings to care for, the parents' absence still pains their children. Gabriela Garcia, whose parents divorced when she was nine years old, recounted how she managed when her mother worked the graveyard shift:

After my parents divorced, my mother was working two shifts. She would work basically from three in the afternoon till seven in the morning. She would be gone by the time I had come home from school. And then I was by myself... So I slept by myself. I had to have the radio, the TV, and the light on because I was so scared sometimes.

Research on gender relations among salaried professionals indicates that gains in gender equality have been uneven. Even when there is greater male involvement in childcare in these families, women continue to perform more of the household labor than their husband (Chen, 1992; Min, 1998; Pesquera, 1993). Moreover, Pesquera (1993: 185) reports that, for the most part, the only way women have altered the distribution of household labor has been through conflict and confrontation, suggesting that ideologically most men continue to view housework as women's work. These findings remind us that professional women, like most other working women, have to juggle full-time work outside the home with the responsibilities of child care and housework. Cecilia Bonus, a nurse mother of three young children, confided that she felt overwhelmed by the never-ending chores: "Here you have to work so hard. You have to do everything. You have to wash the dishes, you have to do laundry, you have to clean the house, you have to take care of the kids. It's just endless..." Although Cecilia's husband took care of the children when she worked the night shifts, she wished that he would do more:

The husbands should help out more, I think...as far as the children go, and the housework... That's one thing I like about Western culture. They have more liberty as a female and the rights that men have. It's not just a one-way thing where 
women have to do everything. Men should do things like chores at home, too, you

know...

38 missed the "helpers" that she had in the Philippines. "Over there, you have maids to help you", she said. "You don't have to do the chores. You have one maid for each child. Life is so much easier there. Every little thing is offered to you, even a glass of water. I just wished I had a helper here." Like Cecilia, the majority of the women in my study longed for the "helpers" they once had or expected to have, had they stayed in the Philippines. In the United States, instead of enlisting their husbands' help with the housework, these women often chose to "solve" their "double-day syndrome" by hoping to displace it on less privileged women. As Parreñas (2001: 79) correctly observes, "As women transfer their reproductive labor to less and less privileged women, the traditional division of labor in the patriarchal nuclear household has not been significantly renegotiated in various countries in the world." At the same time, in the context of migration in which many Filipina nurses are working in higher-paid jobs but leading lower-status lives, the nurses' desire for "helpers" must also be understood as a longing for the social class status that many once had in the Philippines - one that entails the hiring of less privileged women to carry out the reproductive chores.

\section{Conclusion}

Since 1960, women have dominated the Filipino immigrant population, the majority of whom are nurses. The development of this international mobile labor force is inextricably linked to the history of early twentieth-century U.S. colonialization of the Philippines, the establishment of Americanized professional nursing training in the Philippines, the preference for foreign-trained nurses in U.S. immigration laws, the aggressive recruitment of Filipino nurses by Philippine and U.S. agencies - and the pervasive cultural Americanization of the Philippines, which exhorted Filipinos to regard U.S. culture, political system, and way of life as the model par excellence for Philippine society. In other words, the development of the quintessential Filipina nursing care provider and the origins of Filipino nurse migration are not solely the results of contemporary global restructuring, the "liberalization" of U.S. immigration rules, or individual economic desires, but rather are historical outcomes of early twentieth-century U.S. colonial rule in the Philippines.

The global historical relations that set the context for Filipino nurse migration has ramifications for the personal and family lives of Filipina health professionals. Accordingly, the second half of the paper explores how marriage and family relations are reconstituted in the United States when it was the wives who pioneered migration. In these cases, the women bring both economic and legal status to the marital table. However, the interview data indicate that women's relatively higher resources do not automatically lead to more egalitarian relations. In fact, they may lead to family dissolution and men's bitterness over not meeting their cultural expectations as primary breadwinners. The experiences of these families also underscore just how much work it takes for immigrant families to try to "make it" in the United States. In their pursuit of the "American dream," the Filipino health care professional need the paid and unpaid labor of their entire family. Thus the American mythology of the rugged individualist pulling himself up by his own bootstrap is just that: a myth. These 
life accounts also tell us that the pursuit of the American dream, even when "successful," entails physical and psychic costs, the majority of which are borne by the wives and children of these families. Among the costs are a string of broken dreams along the way - of missed family time, deferred careers, and shortened childhood. In the best scenario, responding to the migration-related challenges, both husbands and wives have become more interdependent and equal as they are forced to rely on each other and on the traditional family for economic security and emotional support. On the other hand, to the extent that the traditional division of labor and male privilege persists, wage work adds to the women's overall workload. My research indicates that both of these tendencies exist, though the increased burdens for women are more obvious.

\section{BIBLIOGRAPHY}

ADVINCULA Anthony D. (2004) Filipino nurses get gov't support for NCLEX Initiative, The Filipino Express Online, 18 (41), Oct., pp. 11-17.

ANDERSON Warwick (1995) “Where every prospect pleases and only man is vile”: laboratory medicine as colonial discourse, in Vicente Rafael Ed., Discrepant histories: translocal essays on Filipino cultures, Philadelphia, Temple University Press, pp. 83-112.

ASPERILLA Purita Falgui (1976) Problems of foreign educated nurses and job satisfaction of Filipino nurses, Academy of Nursing of the Philippine Papers, July-September, pp. 2-13.

BASCH Linda, Nina Glick Schiller, and Cristina Szanton Blanc (1994) Nations unbound: transnational projects, postcolonial predicaments, and deterritorialized nation-states, Langhorn, PA, Gordon and Breach, $344 \mathrm{p}$.

BLUM Linda (1991) Between feminism and labor: the significance of the comparable worth movement, Berkeley, University of California Press, 249 p.

BONACICH Edna and Lucie Cheng (1984) Introduction: a theoretical orientation to international labor migration, in Lucie Cheng and Edna Bonacich Eds., Laborimmigration under capitalism: Asian workers in the United States before World War II, Berkeley, University of California Press, pp. 1-56.

BORJAS George (1990) Friends or strangers: the impact of immigrants on the U.S. economy, New York, Basic Books, $274 \mathrm{p}$.

CAMPOMANES Oscar (1997) New formations of Asian American studies and the question of U.S. imperialism, Positions, 5(2), pp. 523-550.

CHANG Grace (2000) Importing nurses: a moneymaking venture." Dollars \& Sense, September.

CHEN Hsiang Shui (1992) Chinatown no More: Taiwan immigrants in contemporary NewYork, Ithaca, NY, Cornell University Press, $281 \mathrm{p}$.

CHIN Christine B.N. (1998) In service and servitude: foreign female domestic workers and the Malaysian "Modernity" project, New York, Columbia University Press, 299 p. 
CHOY Catherine Ceniza (2003) Empire of care: nursing and migration in Filipino American history, Durham and London, Duke University Press, 257 p.

CORONEL Sheila and Ninotchka Rosca (1993) For the boys: Filipinas expose years of sexual slavery by the U.S. and Japan, Ms., November/December, p. 11.

DILL Bonnie Thornton (1988) Our mother's grief: racial-ethnic women and the maintenance of families," Journal of Family History, 13, pp. 415-31.

EGAN Timothy (1996) Mail-order marriage, immigrant dreams and death, The New York Times, 26 May.

ESPIRITU Yen Le (1997) Asian American women and men: labor, laws, and love, Thousand Oaks, CA, Sage, $143 \mathrm{p}$.

ESPIRITU Yen Le (2003) Home bound: Filipino American lives across cultures, communities, and countries, Berkeley, Los Angeles and London, University of California Press, $271 \mathrm{p}$.

ESPIRITU Yen Le and Diane L. Wolf (2001) The paradox of assimilation: children of Filipino immigrants in San Diego, in Ruben Rumbaut and Alejandro Portes Eds., Ethnicities: children of immigrants in America, Berkeley and New York, University of California Press and Russell Sage Foundation, pp. 188-228.

GLENN Evelyn Nakano (1986) Issei, Nisei, war bride: three generations of Japanese American women at domestic services, Philadelphia, Temple University Press, $290 \mathrm{p}$.

GLENN Evelyn Nakano (2002) Unequal freedom: how race and gender shaped American citizenship and labor, Cambridge, MA, Harvard University Press, 306 p.

GLICK SCHILLER Nina (1997) The situation of transnational studies, Identities, 4 (2), pp. 155-166.

GLICK SCHILLER Nina and Georges Eugene Fouron (2001) Georges woke up laughing: long-distance nationalism and the search for home, Durham and London, Duke University Press, $324 \mathrm{p}$.

GUARZINO Luis Eduardo and Michael Peter Smith (1998) The location of transnationalism, in Michael Peter Smith and Luis Eduardo Guarnizo Eds., Transnationalism from below, New Brunswick, N.J., and London, Transaction Publishers, pp. 3-34.

GUINGONA Teofisto T. Jr. (2001) Transcript of the speech of Vice President and Foreign Affairs Secretary His Excellency Teofisto T. Guingona, Jr., during the $103^{\text {rd }}$ founding anniversary of the Department of Foreign Affairs, Department of Foreign Affairs Auditorium, Philippines, July 11.

HALUALANI Rona Tamiko (1995) The intersecting hegemonic discourses of an Asian mail-order bride catalog: Pilipina 'Oriental butterfly' dolls for sale, Women's Studies in Communication, 18 (1), pp. 45-64.

HOGANSON Kristin L. (1998) Fighting for American manhood: how gender politics provoked the SpanishAmerican and Philippine-American wars, New Haven and London, Yale University Press, 305 p.

HONDAGNEU-SOTELO Pierette (1994) Gendered transitions: Mexican experiences ofimmigration, Berkeley, University of California Press, $258 \mathrm{p}$.

HONDAGNEU-SOTELO Pierette (1999) Introduction: gender and contemporary U.S. immigration, American Behavioral Scientist, 42 (4), pp. 565-576.

HONDAGNEU-SOTELO and Ernestine Avila (1997) “I'm here, but I'm there": the meanings of Latina transnational motherhood Gender \& Society, 11(5), pp. 548-571.

HUNTER Frances (1986) Equal pay for comparable worth, New York, Praeger, 227 p. 
LAWCOCK Larry Arden (1975) Filipino students in the United States and the Philippine independence movement: 1900-1935, Ph.D. dissertation, University of California, Berkeley. LEVITT Peggy (2001) The transnational villagers, Berkeley, University of California Press, 281 p. LIPSITZ George (1998) The possessive investment in whiteness: how white people profit from identity politics, Philadelphia, Temple University Press, 274 p.

LOWE Lisa (1996) Immigrant acts: on Asian American cultural politics, Durham, NC, Duke University Press, $252 \mathrm{p}$.

The Manila Times Internet Edition (2004) Annabel Borromeo: an IT-enabled healthcare, Friday, 5/21.

MASSEY Doreen (1999) Imagining globalization: power-geometries of time-space, in Avtar Brah, Mary J. Hickman, and Mairtin Mac an Ghaill Eds., Global futures: migration, environment and globalization, New York, St. Martin's Press, 243 p.

MASSEY Douglas, Joaquin Arango, Graeme Hugo, Ali Kouaouci, Adela Pellegrino, and J. Edward Taylor (1993) Theories of international migration: a review and appraisal, Population and Development Review, 19 (3), pp. 431-466.

MENJIVAR Cecilia (1999) The intersection of work and gender: Central American women and employment in California, American Behavioral Scientist, 42 (2), pp. 601-627.

MIN Pyong Gap (1998) Changes and conflicts: Korean immigrant families in New York, Needham Heights, MA, Allyn \& Bacon, 133 p.

MOHANTY Chandra (1991) Cartographies of struggle: Third World women and the politics of feminism, in Chandra Mohanty, Ann Russo, and Lourdes Torres Eds., Third World women and the politics of feminism, Bloomington, University of Indiana Press, pp. 1-47.

MOSES Evelyn B (1984) National sample survey of registered nurses, November 1984 [computer file], Rockville, MD, Bureau of Health Professionals.

NEWMAN Louise Michele (1999) White women's rights: the racial origins of feminism in the United States, New York, Oxford University Press, $261 \mathrm{p}$.

OKAMURA Jonathan Y. (1998) Imagining the Filipino American diaspora: transnational relations, identities, and communities, New York and London, Garland Publishing, 153 p.

ONG Paul and Tania Azores (1994) The migration and incorporation of Filipino nurses, in Paul Ong, Edna Bonacich, and Lucie Cheng Eds., The new Asianimmigration in Los Angeles and global restructuring, Philadelphia, Temple University Press, pp. 164-195.

PARREÑAS Rhacel Salazar (2001) Servants of globalization: women, migration, and domestic work, Stanford, Stanford University Press, 309 p.

PEREA Juan F. Ed. (1997) Immigrants out! The new nativism and the anti-immigrant impulse in the United States, New York and London, New York University Press, $342 \mathrm{p}$.

PEREZ Gina M. (2004) The near Northwest side story: migration, displacement, and Puerto Rican families, Berkeley, University of California Press, 276 p.

PESQUERA Beatriz M (1993) “In the beginning he wouldn't lift a spoon”: The division of household labor, in Adela de la Torre and Beatriz M. Pesquera Eds., Building with our hands: new directions in Chicana studies, Berkeley, University of California Press, pp. 181-195.

PESSAR Patricia R. (1984) The linkage between the household and workplace in the experience of Dominican immigrant women in the United States, International Migration Review, 18 (4), pp. 1188-1211. 
PESSAR, Patricia R. (1999) Engendering migration studies: the case of new immigrants in the United States, American Behavioral Scientist, 42 (4), pp. 577-600.

PORTES Alejandro, Luis E. Guarzino, and Patricia Landolt (1999) The study of transnationalism: pitfalls and promises of an emergent research field, Ethnic and Racial Studies, 22 (2), pp. 217-237.

POSADAS Barbara M. and Roland L. Guyotte (1990) Unintentional immigrants: Chicago's Filipino foreign students become settlers, 1900-1941, Journal of American EthnicHistory, Spring, pp. 26-48.

PRESSNER Harriet (1988) Shift work and childcare among young dual-earner American parents, Journal of Marriage and the Family, 50, pp.133-148.

RAFAEL Vicente L. (2000) White love and other events in Filipino history, Durham and London, Duke University Press, 286 p.

SAN JUAN E., Jr. (1998) Beyond postcolonial Theory, New York: St. Martin's Press, 325 p.

STARK Oded (1991) The migration of labour, Cambridge, Basil Blackwell, $406 \mathrm{p}$.

STOLER Ann Laura (1991) Carnal knowledge and imperial power: gender, race, and morality in colonial Asia, in Micaela di Leonardo Ed., Gender at the crossroads of knowledge: feminist anthropology in the postmodern era, Berkeley, University of California Press, pp. 51-101.

TAYLOR, Edward J. (1999) The new economics of labor migration and the role of remittances in the migration process, International Migration, 37, pp. 63-88.

THOMAS Brinley (1973) Migration and economic growth: A study of great Britain and the Atlantic economy, Cambridge, Cambridge University Press, 498 p.

TYNER, James A (1999) The global context of gendered labor: migration from the Philippines to the United States, American Behavioral Scientist, 42 (4), pp. 671-689.

U.S. IMMIGRATION AND NATURALIZATION SERVICE (INS) (2001) 2000 Statistical Yearbook, Washington D.C, U.S. Government Printing Office.

U.S. TREASURY DEPARMENT (2003) U.S.-Philippine agrees to improve remittance services, news release, May 20.

WARREN Jennifer (1993) Suit asks Navy to aid children left in Philippines, Los Angeles Times, 5 March.

YEGENOGLU Meyda (1998) Colonial fantasies: towards a feminist reading ofOrientalism, Cambridge, Cambridge University Press, $182 \mathrm{p}$.

ZOLBERG Aristide (1986) International factors in the formation of refugee movements, International Migration Review, 20 (Summer), pp. 151-169.

\section{NOTES}

1. International migration is so prevalent in the Philippines that in 1997, the Philippine Secretary of Foreign Affairs called for "international migration" to be made a subject for elementary and high school students to prepare them for what he termed the "reality of immigration" (Okamura, 1998: 5).

2. Filipinos comprised the second largest immigrant group, behind Mexicans. According to the 2000 census, Chinese Americans, at more than 2,4 millions, constituted the largest Asian American group in the United States. In California, Chinese Americans, who neared the 1 million mark also pushed past Filipinos (918 678) to become the state's largest Asian group. Though the 
Filipino population rose by $31,5 \%$ nationwide and $25,6 \%$ statewide, it fell well short of predictions that the 2000 census would crown Filipinos as the largest Asian group in the nation and in California.

3. Beginning in the early 1960s, as the demand for nursing education exceeded the enrollment slots available in Philippine colleges and schools of nursing, Filipino businessmen and health educators opened new schools of nursing in the provinces as well as in urban areas. Between 1950 and 1970, the number of nursing schools in the Philippines increased from just seventeen to 140 (Choy, 2003).

4. The 1965 Immigration Act, which abolished the national-origins quotas and permitted entry based primarily on family reunification or occupational characteristics, dramatically increased the number of Asian immigrants to the United States.

5. Catherine Choy's Empire of Care is the first and only study on the introduction of nursing in the Philippines during U.S. colonial rule and on the impact of the U.S. Exchange Visitor Program of the 1950s and 1960s on Filipino migration to the United States. Therefore, this section of my paper necessarily relies on Choy's pioneering research.

6. In his 1936 extraordinary popular autobiography, Victor Heiser, the commissioner of health in the Philippines, described Filipinos in the following terms: "grown-up children, dirty, unsanitary, diseased, ignorant, unscrupulous, superstitious, born actors, resigned to death, untrustworthy, cowards, a nation of invalids, incubators of leprosy, unhygienic"(cited in Anderson, 1995: 100).

7. In 1970, a U.S. immigration amendment introduced the H-1 temporary work visa program, which enables a hospital or nursing home to sponsor or bring a nurse with a professional license from abroad to work in the United States for two years. However, under this program, applicants must pass the U.S. nurses' licensing exam. If she passes, she can gain permanent residency after two years. If she fails the exam, she loses her temporary work visa status and faces the threat of deportation (Chang, 2000). The majority of foreign-trained nurses (between 75 to 90 percent) who took the exam failed (Ong and Azores, 1994). In 1989, the Filipina Nurses Organization fought for passage of the Immigration Nursing Relief Act, which enabled H-1 visa nurses who were present in the United States on September 1, 1989, and had worked for three years as a registered nurse in the United States, to adjust their status to permanent resident (Ong and Azores, 1994).

8. -According to the Philippine Overseas Employment Administration, between 1989 and 1993, Filipino Americans remitted approximately five billion dollars, averaging well over one billion dollars each year (Okamura, 1998: 126). By 1989, consumer goods sent via balikbayan (returnee or homecomer) boxes contributed 4.2 billion pesos (or one hundred and ninety million dollars) annually to the Philippine economy (Basch, Glick Schiller, and Szanton Blanc, 1994: 257-58). These numbers are rising. In the first half of 1994, overseas Filipinos remitted almost eight hundred million dollars through official bank transfers - a likely underestimate (Okamura, 1998: $44,126)$. In 2001, over seven million overseas Filipino workers sent over six billion dollars in remittances to the Philippines (U.S. Treasury Department, 2003).

9. Over the course of eight years (1992-2000), I interviewed just over one hundred Filipinos in San Diego County. The majority of the interviewees were Filipino Navy men, Filipino nurses and their families.

10. During the ninety-four years of U.S. military presence in the Philippines, U.S. bases served as recruiting stations for the U.S. Navy. Filipinos were the only foreign nationals who were allowed to enlist in the U.S. armed forces; and the Navy was the only military branch they could join. As a result, Filipino sailors have always formed a significant segment of the Filipino community in the United States, especially in San Diego, the home of the largest U.S. naval base and the Navy's primary West Coast training facility until 1998.

11. Data from the 1984 National Sample Survey of Registered Nurses indicate that Filipinas had the highest earnings among all groups, averaging almost five thousand dollars more annually 
than white nurses (Moses, 1984). Ong and Azores (1994) report that Filipina nurses use various strategies to increase their earnings: working double shifts or in the higher-paying evening and night shifts, and in inner-city hospitals which offer higher salaries than the national average. In other words, they earn more because they are more likely to work under the least desirable conditions.

\section{ABSTRACTS}

Since the 1960s, the Philippines has sent the largest number of professional immigrants to the United States, the majority of whom are Filipino health care practitioners. Linking U.S. imperialism and migration to the United States, this article argues that the overrepresentation of nurses among contemporary Filipino immigrants is the result of intertwined influences of U.S. (neo)colonialism in the Philippines, the establishment of Americanized professional nursing training in the Philippines, the recurring shortage of nurses in the United States, and the aggressive recruitment of Filipino nurses by Philippine and U.S. agencies. The global historical relations that set the context for Filipino nurse migration has ramifications for the personal and family lives of Filipina health professionals. Accordingly, the second half of the paper explores how marriage and family relations are reconstituted in the United States when it was the wives who pioneered migration.

Sexe, migration et travail : les professionnels Philippins de la santé aux Etats-Unis. Depuis les années 1960, les Philippins ont envoyé un grand nombre d'immigrants professionnels vers les États-unis, la majorité d'entre eux étant des praticiens de la santé. En liant l'impérialisme américain et la migration aux États-Unis, cet article avance que la sur-représentation des infirmières parmi les immigrants philippins actuels est le résultat d'influences imbriquées : le néo-colonialisme américain aux Philippines, l'établissement de centres de formation d'infirmières aux Philippines, le manque récurrent d'infirmières aux États-Unis et le recrutement «accrocheur» des infirmières par l'État Philippin et les agences américaines. Les liens historiques qui sont à l'origine du contexte de la migration des infirmières philippines ont des ramifications dans les vies personnelles et familiales des professionnelles de la santé. Par conséquent, la deuxième partie de l'article traite de la façon dont les relations familiales et matrimoniales se reconstituent aux États-unis lorsque les épouses étaient les premières à partir en migration.

Sexo, migración y trabajo : las profesionales filipinas de la sanidad en Estados Unidos Desde los años 1960, un gran número de inmigrantes profesionales filipinos, la mayoría de entre ellos practicantes de la sanidad, se ha instalado en Estados Unidos. Asociando el imperialismo americano y la migración a Estados Unidos, este artículo sugiere que la representación de las enfermeras entre los inmigrantes filipinos actuales es el resultado de diferentes influencias que se imbrican unas con otras: el neo-colonialismo americano en Filipinas, el establecimiento de centros de formación de enfermeras en Filipinas, la carencia recurrente de enfermeras en Estados Unidos y la contratación de « enganchador » de enfermeras por el Estado Filipino y las agencias americanas. Los 
INDEX

Mots-clés: femmes, Philippins, relations avec le pays d'origine, relations familiales, santé Geographical index: États-Unis

\section{AUTHOR}

\section{YEN LE ESPIRITU}

Ethnic Studies, University of California, San Diego, yespiritu@ucsd.edu 